\title{
PENGEMBANGAN LEMBAR KERJA PESERTA DIDIK MATERI KEANEKARAGAMAN HAYATI BERDASARKAN DIVERSITAS IKAN SUNGAI AUR LEMAU BENGKULU
}

\author{
Intan Febrian $^{1^{*}}$, Abdul Rahman Singkam ${ }^{1}$, Aceng Ruyani ${ }^{1}$ \\ ${ }^{1}$ Program Studi Pendidikan Biologi, Fakultas Keguruan dan Ilmu Pendidikan, Universitas Bengkulu \\ Email: Intanfebrian87@yahoo.com
}

\begin{abstract}
Abstrak
Penelitian ini bertujuan untuk mengetahui hasil validasi dan uji keterbacaan Lembar Kerja Peserta Didik (LKPD) materi keanekaragaman hayati berdasarkan hasil penelitian keanekaragaman jenis ikan di Sungai Aur Lemau Bengkulu. Teknik pengumpulan data pada penelitian ini adalah angket (kuisioner). Instrumen yang digunakan adalah lembar angket (kuisioner) untuk tiga orang validator (dua orang Dosen Program Studi Pendidikan Biologi dan Guru Biologi SMA kelas X), dan lembar keterbacaan untuk peserta didik. LKPD yang disusun memperoleh kriteria sangat valid, dengan nilai 92,2\% dari para validator, dan juga dinilai sangat layak dengan nilai 95,32\% dalam uji keterbacaan oleh 30 orang peserta didik di SMAN 6 Kota Bengkulu. Hasil validasi dan uji keterbacaan ini menunjukkan bahwa LKPD yang disusun layak digunakan sebagai bahan ajar materi keanekaragaman hayati kelas $X$ tingkat SMA.
\end{abstract}

Kata Kunci : Lembar Kerja Peserta Didik, Keanekaragaman hayati, Ikan air tawar

\begin{abstract}
This study aimed to determine the validity and the readability of a Students' Worksheet on biodiversity topic based on the diversity of fishes in Aur Lemau River Bengkulu. The data collection technique in this study was a questionnaire. The used instruments were questionnaires for validators (two Biology Education Lecturers and Senior High School Biology teachers in grade 10), and readability sheet for students. The compiled Students' Worksheet obtained "a very valid" criteria, with $92.2 \%$ as an average score from the validators, and also was considered "a very feasible" with average value of $95.32 \%$ in the readability tests by 30 students at Senior High School number 6 Bengkulu. The results of validity and readability tests showed that the prepared Students' Worksheet is appropriated to be one of teaching material for biodiversity topic for grade 10 level.
\end{abstract}

Keywords: Students' worksheet, biodiversity, freshwater fish

\section{PENDAHULUAN}

Indonesia memiliki sumber daya perairan tawar yang sangat luas. Sumber daya perairan tawar ini antara lain danau, rawa, situ, dan telaga, mata air dan sungai. Provinsi Bengkulu memiliki sumberdaya perairan tawar seluas 5.324 $\mathrm{km}^{2}$ (Kementerian PUPR, 2017). Salah satu sumberdaya perairan tawar yang mendominasi di Provinsi Bengkulu adalah sungai. Sungai-sungai di Bengkulu antara lain: Sungai Ketahun, Sungai Alas, Sungai Padang Guci, Air Nipis Seginim, Air Musi, Sungai Aur Lemau dan lain-lain.
Sumberdaya perairan tawar sungai seharusnya berasosiasi dengan keragaman biota yang tinggi. Salah satu biota yang diharapkan memiliki kelimpahan individu dan jenis yang tinggi di sungai adalah ikan. Keanekaragaman jenis ikan yang tinggi ini memiliki potensi yang tinggi terutama sebagai sebagai sumber pangan yang kaya gizi. Data kementerian kelautan dan perikanan Republik Indonesia 2016 (BKIPM KKP, 2015), menunjukkan bahwa data konsumsi ikan mencapai 43,9 kg perkapita 
pertahun.

Tinggi-rendahnya

keanekaragaman dan kelimpahan ikan pada suatu kawasan juga dapat dijadikan sebagai indikator tingkat kesehatan perairan diarea tersebut (Wahyuni, 2018).

Keberadaan potensi keragaman ikan di sungai air limau juga dapat dimanfaatkan sebagai sumber belajar. Pembelajaran akan lebih baik apabila melibatkan lingkungan terutama pada materi keanekaragaman hayati. Potensi sumber belajar tersebut harus dikembangkan dalam bentuk bahan ajar yang lebih praktis.

Bahan ajar merupakan segala bahan (baik informasi, alat, maupun teks) yang disusun secara sistematis, yang menampilkan keseluruhan kompetensi yang akan dikuasai peserta didik dan digunakan dalam proses pembelajaran. Beberapa contoh bahan ajar adalah buku pelajaran, modul, handout, LKS, model atau maket, bahan ajar audio bahan ajar interaktif dan sebagainya (Prastowo, 2015). Bahan ajar dapat dikembangkan dari berbagai macam sumber di sekitar kita. Salah satunya terciptanya inovasi dan kreativitas dalam menjadikan sumber belajar lingkungan menjadi bahan ajar yang menarik bagi peserta didik (Widyantini, 2013).

Berdasarkan uraian di atas, peneliti tertarik melakukan pengembangan sumber belajar yang mengacu pada lingkungan peserta didik. Bahan yang dikembangkan berupa lembar kerja peserta didik (LKPD). LKPD miliki kepratiksan dalam membantu peserta didik maupun guru dalam proses pembelajaran (Trianto, 2012). Pengembangan LKPD dapat dilakukan dengan mengintergrasikan informasi potensi lokal.

Pengembangan LKPD berbasis penelitian keragaman jenis ikan di Sungai Air Limau dapat mendukung pembelajaran Biologi. LKPD yang dikembangkan dapat memberdayakan pengetahuan siswa terkait lingkungan sekitar meraka. Pengetahuan melalui LKPD merupakan upaya awal dari kegaitan konservasi kekayaan keanekaragaman hayati jenis ikan di Sungai Air Limau.

\section{METODE}

Penelitian ini merupakan jenis Penelitian dan pengembangan atau Research and Development (R\&D) yang dikembangkan oleh Sugiyono. Penelitian dilaksanakan pada bulan April 2019 di SMA Negeri 6 Kota Bengkulu. Subjek uji coba dalam penelitian ini adalah peserta didik kelas X MIPA D SMA Negeri 6 Kota Bengkulu. Teknik pengumpulan data dalam penelitian ini menggunakan lembar angket (kuesioner) yang terdiri atas angket uji kelayakan untuk validator (ahli materi, ahli media, dan guru Biologi SMA kelas X), dan angket uji keterbacaan LKPD untuk peserta didik.

Data uji validasi dan uji keterbacaan yang terkumpul dianalisis secara deskriptif kuantitatif. Angka hasil uji yang diperoleh diubah ke dalam persentase kelayakan dengan rumus:

$\begin{array}{ll}\frac{\text { Jumlah Skor Lembar Validasi }}{\text { Skor Maksimal }} & \times 100 \% \\ & \text { Riduwan (2015) }\end{array}$

Persentase skor yang diperoleh dari masing-masing validator kemudian dirataratakan dengan menggunakan rumus sebagai berikut:

$$
X=\frac{\sum A}{n}
$$

Keterangan:

$$
\begin{array}{ll}
\mathrm{X} & \text { : Nilai rata-rata validator } \\
\mathrm{\Sigma A} & \begin{array}{l}
\text { : Jumlah skor yang didapatkan dari } \\
\text { tiap validator }
\end{array} \\
\mathrm{n} & \text { : Jumlah validator }
\end{array}
$$

Nilai rata-rata skor dari ketiga validator, kemudian diinterpretasikan pada kategori kualitatif yang dapat dilihat pada Tabel 1. 
Tabel 1. Kriteria Interpretasi Skor UjiKelayakan

\begin{tabular}{cc}
\hline Persentase & Kriteria \\
\hline $81 \%-100 \%$ & SangatLayak \\
$61 \%-80 \%$ & Layak \\
$41 \%-60 \%$ & CukupLayak \\
$21 \%-40 \%$ & KurangLayak \\
$0 \%-20 \%$ & Tidak Layak \\
\hline & Riduwan (2015)
\end{tabular}

Lembar Kerja peserta didik dapat dikatakan layak jika persentase skor Validasi dan Uji keterbacaan yang di peroleh lebih dari $61 \%$.

\section{HASIL DAN PEMBAHASAN}

Berdasarkan hasil validasi LKPD oleh ahli materi, ahli media dan guru Biologi di peroleh kriteria sangat layak dengan persentase 92,2\%. Data hasil validasi LKPD oleh validator dapat dilihat pada Tabel 2.

Tabel 2. Hasil Uji Kelayakan LKPD dari Validator

\begin{tabular}{cccc}
\hline No. & Validator & Persentase & Kriteria \\
\hline 1. & Ahli Materi & $88,5 \%$ & $\begin{array}{c}\text { Sangat } \\
\text { Layak }\end{array}$ \\
2. (Ahli Media) & $95 \%$ & $\begin{array}{c}\text { Sangat } \\
\text { Layak }\end{array}$ \\
3. Biologi SMA & $93,3 \%$ & $\begin{array}{l}\text { Sangat } \\
\text { Layak } \\
\text { kelas X) }\end{array}$ \\
\hline
\end{tabular}

Beberapa poin yang perlu diperbaiki menurut validator sebelum LKPD dilanjutkan keuji keterbacaan oleh peserta didik di sekolah adalah sebagai berikut:

1. Desain cover sebaiknya ditambahkan foto penelitian yang paling bagus dan gambar ikan pada cover diperbesar.

2. Tujuan pembelajaran di LKPD seharusnya siswa dapat memahami keanekaragaman tingkat jenis melalui pengamatan morfologi ikan.

3. Di bagian konsep seharusnya disisipkan peta supaya peserta didik lebih mengenal lokasi Sungai Aur Lemau Bengkulu.
4. Tabung sampel seharusnya diganti dengan gambar tabung yang asli.

Beberapa hal yang diperbaiki berdasarkan saran dari validator dapat dilihat pada Gambar 1, Gambar 2, Gambar 3 dan Gambar 4:

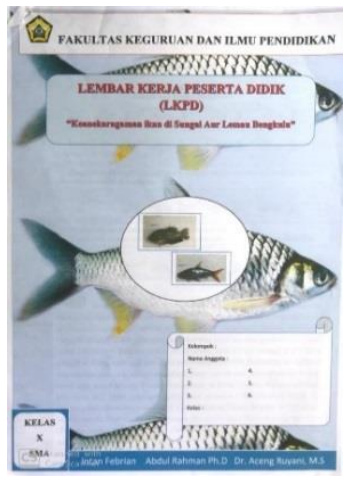

Sebelum Revisi

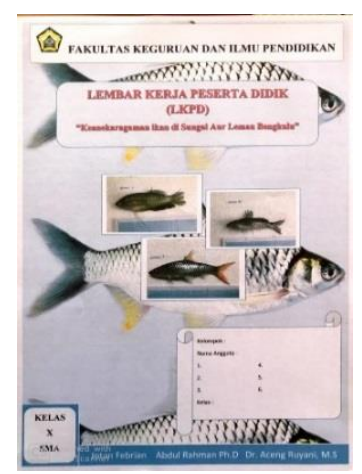

Sesudah Revisi
Gambar 1. Pemilihan gambar ikan pada cover sebelum dan sesudah revisi

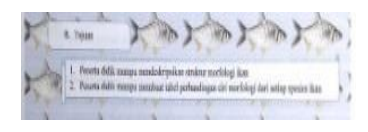

Sebelum Revisi
Gambar 2. Perbaikan tujuan kegiatan pengamatan sebelum dan sesudah revisi

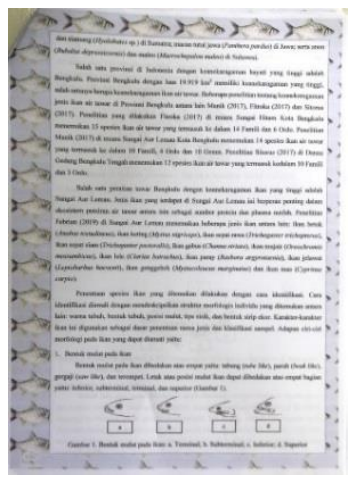

Sebelum Revisi

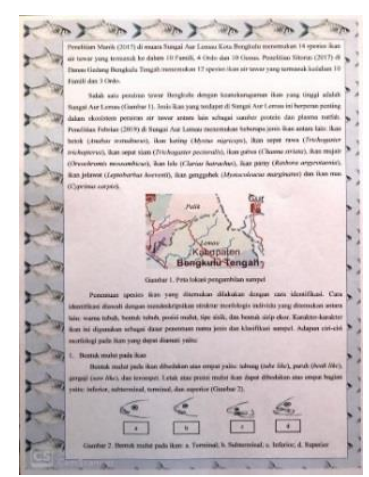

Sesudah Revisi
Gambar 3. Penambahan peta di konsep sebelum dan sesudah revisi 


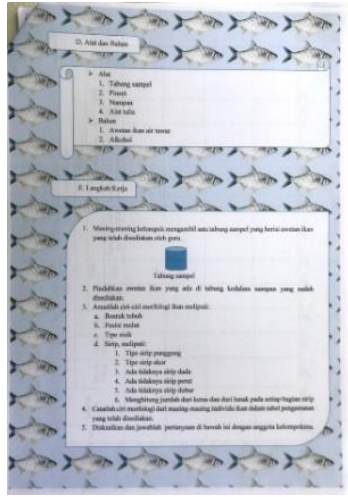

Sebelum Revisi

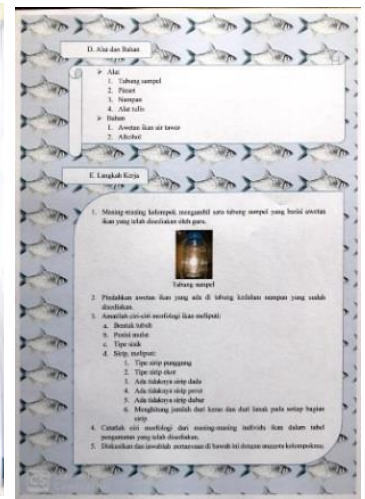

Sesudah Revisi

Gambar 4. Perbaikan gambar tabung sampel sebelum dan sesudah

revisi

Setelah dilakukan revisi terhadap LKPD dilanjutkan dengan uji keterbacaan LKPD pada siswa kelas X MIPA D SMAN 6 Kota Bengkulu. Pada hasil uji keterbacaan LKPD, LKPD dinilai sangat layak dengan skor rata-rata 95,32\%. Skor rata-rata LKPD dapat dilihat pada Tabel 3.

Tabel 3. Hasil Uji Keterbacaan LKPD Ikan di Sungai Aur Lemau Bengkulu oleh Peserta Didik Kelas X MIPA D SMAN 06 Kota Bengkulu

\begin{tabular}{|c|c|c|c|c|c|}
\hline \multirow{2}{*}{ No. } & \multirow{2}{*}{ Indikator } & \multicolumn{2}{|c|}{$\mathrm{Ya}$} & \multicolumn{2}{|c|}{ Tidak } \\
\hline & & Jumlah & $\%$ & Jumlah & $\%$ \\
\hline 1. & $\begin{array}{l}\text { Struktur LKPD disusun secara sistematis/urut } \\
\text { sehingga saya mudah memahami }\end{array}$ & 30 & 100 & - & - \\
\hline 2. & $\begin{array}{l}\text { Kegiatan yang disajikan dalam LKPD mempunyai } \\
\text { tujuan yang jelas }\end{array}$ & 30 & 100 & - & - \\
\hline 3. & $\begin{array}{l}\text { Kegiatan yang disajikan dalam LKPD dapat } \\
\text { merangsang keingintahuan saya }\end{array}$ & 28 & 93,3 & 2 & 6,7 \\
\hline 4. & $\begin{array}{l}\text { Penampilan LKPD membuat saya tertarik untuk } \\
\text { mengerjakannya }\end{array}$ & 21 & 70 & 9 & 30 \\
\hline 5. & $\begin{array}{l}\text { Penyajian LKPD dilengkapi dengan gambar dan } \\
\text { ilustrasi sehingga membantu saya memahami } \\
\text { materi }\end{array}$ & 30 & 100 & - & - \\
\hline 6. & $\begin{array}{l}\text { Susunan kalimat yang disajikan jelas, sederhana, } \\
\text { dan mudah saya mengerti }\end{array}$ & 28 & 93,3 & 2 & 6,7 \\
\hline 7. & Bahasa yang digunakan dapat saya pahami & 30 & 100 & - & - \\
\hline 8. & $\begin{array}{l}\text { Bahasa yang disajikan sesuai dengan tingkat } \\
\text { perkembangan saya }\end{array}$ & 29 & 96,6 & 1 & 3,4 \\
\hline 9. & $\begin{array}{l}\text { Saya mudah memahami petunjuk/arahan dalam } \\
\text { LKPD }\end{array}$ & 30 & 100 & - & - \\
\hline 10. & $\begin{array}{l}\text { Pertanyaan yang disajikan dalam LKPD mudah saya } \\
\text { pahami }\end{array}$ & 30 & 100 & - & - \\
\hline & Jumlah rata-rata persentase & 95, & & & \\
\hline
\end{tabular}

Dari hasil uji keterbacaan LKPD menghasilkan nilai yang lebih rendah dibandingkan dengan aspek lain. Hal ini dikarenakan terlalu banyaknya materi pada LKPD sehingga peserta didik tidak tertarik untuk membaca LKPD tersebut. Hal ini selaras dengan saran dari peserta didik, dimana peserta didik menyarankan untuk materi pada LKPD tidak terlalu panjang dan materi pada LKPD dipersingkat lagi supaya peserta didik lebih mudah memahaminya. Menurut Darmojo (1992) LKPD harus memenuhi syarat antara lain syarat konstruksi. Syarat kontruksi adalah syarat yang berkenaan dengan penggunaan bahasa, susunan kalimat, kosakata, tingkat kesukaran, dan kejelasan yang pada hakikatnya supaya lebih mudah dimengerti oleh peserta didik. 
Dari hasil penilaian oleh peserta didik, LKPD dinilai sangat layak dengan skor rata-rata 95,32\%. Berdasarkan hasil uji keterbacaan oleh peserta didik ini, maka LKPD tersebut dapat digunakan sebagai bahan ajar pada materi keanekaragaman hayati. Hasil penelitian yang didapatkan selaras dengan penelitian Fajri (2018) mengenai LKPD materi Vertebrata Kelas Pisces kelas X MIPA 2 yang juga mendapatkan respon sangat baik. 20 dari 27 peserta didik yang mengisi angket respon Fajri (2018) memberi tanggapan positif $100 \%$, dan tujuh peserta didik yang lain sebesar $96 \%$. Selain itu penelitian Uniati (2019), mengenai pengembangan LKPD pada Materi Keanekaragaman Hayati mendapatkan kriteria sangat baik dengan presentase $93 \%$.

Keunggulan utama LKPD ini dibanding buatan penerbit adalah LKPD ini disusun berdasarkan sumber belajar lingkungan sekitar sehingga lebih aplikatif dan bermakna. Hal ini dapat meningkatkan motivasi peserta didik dalam belajar serta meningkatkan sikap peduli lingkungan para peserta didik terhadap kejadian yang ada di lingkungan sekitar. Sesuai pernyataan Susanti (2013), yang menyatakan penggunaan lingkungan sekitar sebagai sumber belajar dapat membuat siswa mengetahui hal-hal yang terjadi di lingkungan sekitar. Selai itu, siswa mampu untuk mengaplikasikannya dalam kegiatan sehari-hari. Tivani (2016) menyatakan bahwa permasalahan yang diangkat dalam pembelajaran harusnya berasal dari permasalahan nyata yang dihadapi peserta didik. Pitasari (2018), juga menjelaskan bahwa ilmu biologi merupakan ilmu yang berkaitan erat dengan peristiwa yang terjadi dalam kehidupan sehari-hari .

LKPD penerbit memiliki beberapa kelemahan yang dapat dilihat dari aspek materi. LKPD penerbit juga tidak mengangkat potensi lokal yang ada di sekitar. Dilihat dari aspek materi LKPD dari penerbit, pada umumnya belum sesuai dengan pengertian LKPD sesungguhnya, LKPD yang digunakan hanya berisi soalsoal latihan yang kemudian dikerjakan oleh peserta didik tanpa memahami materi terlebih dahulu. Sedangkan menurut Depdiknas (2008) LKPD yang baik adalah LKPD yang memiliki komponen penyusun yang lengkap yaitu judul, KD, tujuan, materi/konsep, prosedur kerja dan evaluasi. Para guru di sekolah hendaknya lebih mengutamakan penggunaan LKPD buatan sendiri dengan memakai materi sumber belajar lingkungan sekitar. Hal ini bertujuan agar pembelajaran lebih konstekual, dan siswa lebih memahami dan lebih peduli potensi lokal yang ada di lingkungan sekitar. Penelitian Rarasandy (2013), menyimpulkan bahwa pembelajaran biologi yang mengarah pada penanaman karakter peduli lingkungan dapat meningkatkan kepedulian siswa terhadap lingkungan dan penguasaan konsep siswa pada materi pengelolaan lingkungan

Selain itu penggunaan LKPD dalam pembelajaran membuat peserta didik dapat lebih aktif menemukan sendiri pengetahuan. Hal ini didukung oleh Yasir (2013), menurutnya LKPD itu sendiri berfungsi sebagai bahan ajar yang memberikan kesempatan kepada peserta didik untuk belajar secara mandiri. Menurut Trianto (2010) Lembar Kerja Peserta Didik (LKPD) merupakan panduan peserta didik yang digunakan untuk melakukan pengembangan aspek kognitif maupun panduan untuk pengembangan semua aspek pembelajaran dalam bentuk panduan kegiatan penyelidikan atau pemecahan masalah sesuai indikator pencapaian hasil belajar yang harus dicapai. 


\section{PENUTUP}

\section{Simpulan}

Tingkat kelayakan LKPD berdasarkan uji validasi ahli memperoleh persentase 92,2 \% dengan kategori "Sangat Layak" dan uji keterbacaan peserta didik memperoleh persentase 95,32 \% dengan kategori "Sangat Layak". Hal ini berarti, LKPD berdasarkan diversitas ikan sungai Aur Lemau Bengkulu layak digunakan sebagai bahan ajar matapelajaran biologi.

\section{Saran}

LKPD ini sebaiknya dikembangkan lagi oleh peneliti selanjutnya dan dilanjutkan dengan uji efektivitas.

\section{DAFTAR PUSTAKA}

Badan Karantina Ikan Pengendalian Mutu Kementerian Kelautan dan Perikanan Republik Indonesia (Bkipm KKP RI). 2015. Permasalahan Konsumsi dan Manfaat Ikan. Jakarta.

Darmojo, Hendro dan Jenny R.F. Kaligis. 1992. Pendidikan IPA II. Jakarta: Depdiknas.

Depdiknas. 2008. Panduan Pengembangan Bahan Ajar. Jakarta: Direktorat Pembinaan Sekolah Menengah Atas.

Fajri, A., Singkam, A. R., dan Ariefa, P. Y. 2018. Pengembangan Lembar Kerja Peserta didik Materi Vertebrata Kelas X Berdasarkan Inventarisasi Ikan Laut. Jurnal Pendidikan dan Pembelajaran Biologi 2 (2): 52-57.

Kementerian PUPR. 2017. Buku Informasi Statistik 2017. Jakarta.

Pitasari, Y., Abdul, R., Kasrina. 2018. Pengembangan Lembar Kerja
Peserta Didik Berdasarkan Studi Pengaruh Osmosis Terhadap Warna Mata. Diklabio: Jurnal Pendidikan dan Pembelajarn Biologi 2 (2) : 16-21. (Online),

Prastowo, A. 2015. Panduan Kreatif Membuat Bahan Ajar. Yogyakarta: Diva Press.

Rarasandy, L., Dyah, R.I., dan Kukuh, S. 2013. Pembelajaran Biologi Mengarah Pada Penanaman Karakter Peduli Lingkungan Pada Materi Pengelolaan Lingkungan. Lembaran IImu Kependidikan 42 (2): 129-136.

Susanti, N.D. 2013. Memanfaatkan Lingkungan Sekitar Sebagai Sumber Belajar Dengan Tema Lingkungan Untuk Meningkatkan Hasil Belajar Siswa Kelas lii Sekolah Dasar. Jurnal Penelitian Pendidikan Guru Sekolah Dasar 1 (2): 1-11.

Tivani, I., dan Paidi. 2016. Pengembangan LKS Biologi Berbasis Masalah untuk Meningkatkan Kemampuan Pemecahan Masalah dan Karakter Peduli Lingkungan. Jurnal Inovasi Pendidikan 2(1): 35-45. (Online),

Trianto. 2010. Pengantar Penelitian Pendidikan Bagi Pengembangan Profesi. Jakarta: Kencana.

Trianto. 2012. Model Pembelajaran Terpadu. Jakarta: PT Bumi Aksara.

Uniati, O., Dewi, J.,dan Ariefa, P.Y. 2019. Pengembangan Lembar Kerja Peserta Didik Berdasarkan Keragaman Jenis Tanaman Di Green Chemistry Dan Kebun Biologi Universitas Bengkulu. 
Jurnal Pendidikan dan Pembelajaran Biologi 3(1): 17-24.

Yasir, M., Susantini, E., dan Isnawati. 2013. Pengembangan lembar kerja Siswa (LKS) Berbasis Stretegi Belajar metakognitif untuk meningkatkan hasil belajar siswa pada materi pewarisan sifat manusia. BioEdu. 2(1): 77-82.

Wahyuni, T.T dan Agus Z. 2018. Keanekaragaman Ikan di Sungai Luk Ulo Kabupaten Kebumen. Biosfera. 35 (1): 23-28.

Widyantini, T. 2013. Penyusunan Lembar Kegiatan Peserta $\operatorname{ddik(LKPD)}$ sebagai Bahan Ajar. Yogyakarta: PPPP TK Matematika. 